This item was submitted to Loughborough's Institutional Repository (https://dspace.lboro.ac.uk/) by the author and is made available under the following Creative Commons Licence conditions.

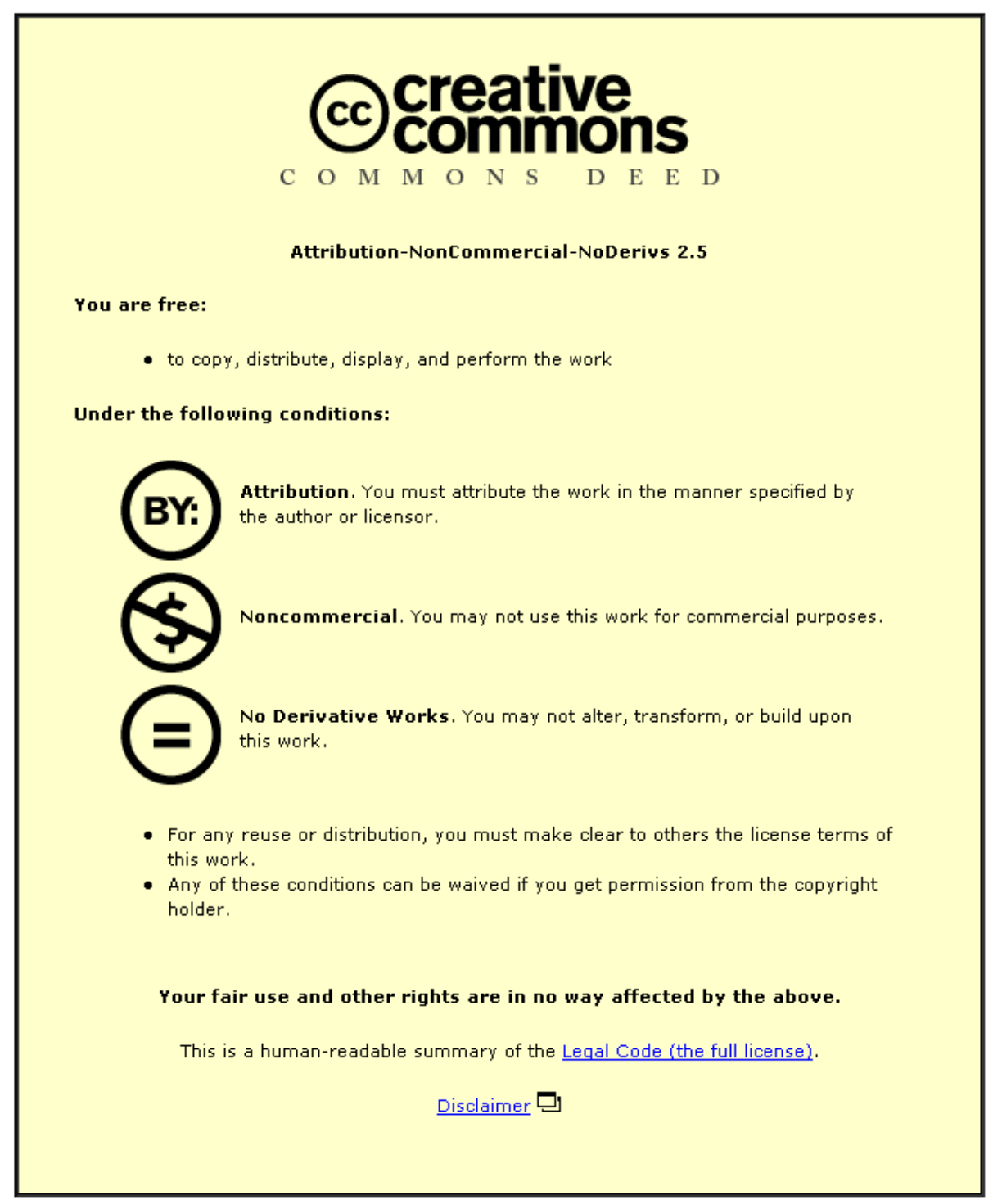

For the full text of this licence, please go to: http://creativecommons.org/licenses/by-nc-nd/2.5/ 

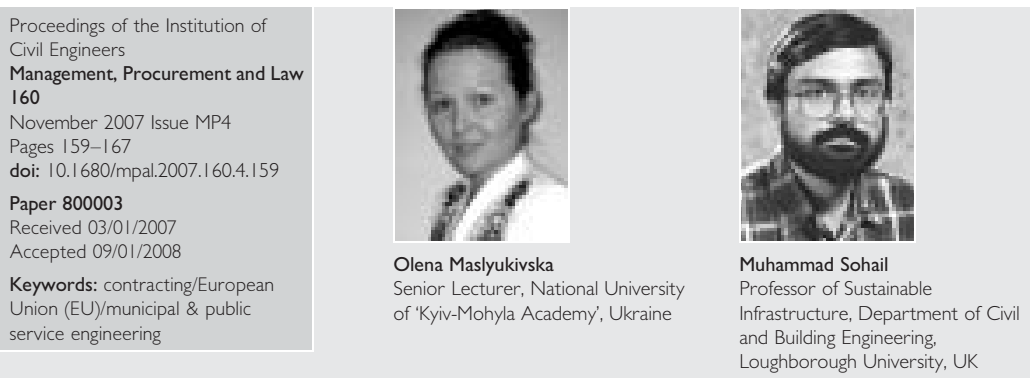

\section{European infrastructure procurement through PPP}

O. Maslyukivska and M. Sohail

European countries are introducing changes to their legislation and institutions that enable infrastructure procurement through public-private partnerships (PPPs). The purpose of this paper is to survey the legislation and institutions for infrastructure procurement through PPPs across Europe. Procurement procedures have no defined status in the regulatory framework of the European Union (EU); as a consequence, each member state has developed its own PPP legal and institutional framework. As such the process of procurement varies widely between the member states. The legislative frameworks for PPPs are discussed with reference to central and eastern Europe. This paper finds that effective legal, regulatory and contractual conditions perform successfully when they are based on and supported by the institutional framework of a country. A majority of European countries have realised this necessity and have developed various institutional framework models accordingly. These models are defined according to the degree of centralisation of PPP institutions in a country's overall state structure; the models are: highly centralised (western newly independent states); highly decentralised (France and Portugal); and mixed centralised and decentralised (Ireland, the UK, Italy and the Netherlands). The changing institutional framework in new member states is described with reference to the Czech Republic, Hungary and Poland.

\section{INTRODUCTION}

Public services and infrastructure investment are essential to the competitiveness of European economies; however, investment varies according to the social and economic disparities between countries. Trans-European transport networks (TEN-Ts) and public services such as water and wastewater management, solid waste and energy operation are among the areas most in need of investment. ${ }^{1}$ Most local infrastructure rehabilitation and construction in the region is carried out under contracts to local or even international construction companies. Increasingly, services such as solid waste collection, maintenance of green areas, management of public lighting and water and sanitation services are delivered by private providers, which are contracted by local government units under competitive bidding procedures. Furthermore, inefficiencies, lack of modern operating and managerial techniques and limited access to technologies encourage partnerships with those who do have this expertise. This paper is concerned with procurement (the process of buying the goods, works or services) of infrastructure through public-private partnerships (PPPs).

A number of the new member states of the European Union (EU) have additional investment requirements arising from their transition towards new economic, social and political systems. For example, many of the new member states have relied historically on railways; hence their motorway networks require considerable investment. The World Bank estimated the infrastructure investment needs for the accession candidates to be $€ 65$ billion from 2003 over the next 15 years. ${ }^{2}$ It cites Poland as the country with the highest infrastructure investment needs (€21.4 billion), followed by the Czech Republic, Bulgaria,

Romania, Hungary, Slovakia, Estonia, Slovenia, Lithuania and Latvia, with some $70 \%$ of these investment requirements being at municipal or regional levels of government. ${ }^{3}$ The private sector has been called in to bridge the gap between the required investments in infrastructure rehabilitation/expansion and the available internal and external funding.

Investors are usually attracted to countries that have a stable and transparent regulatory framework, one that supports fair competition and establishes the rights and duties of the parties. In the case of PPPs, investors will be looking for a bankable project and a regulatory climate that will protect them against the perceived risks of doing business in the region. The development of a sustainable regulatory PPP framework would, from the other side, protect public authorities from the risk of losing control over strategically significant spheres of work, and would provide guarantees to the general public-the consumers of services and products. Drafting and enforcement of such legislation is on the agendas of the European countries.

In order to cover these needs, as well as to ensure that development strategies are executed effectively, the legislative and institutional framework for PPPs across the region must evolve further. This paper discusses the changes that are being introduced to legislation at local, regional and European levels, and surveys the institutions supporting the promotion of PPPs that are being established.

\section{METHODOLOGY}

The paper is based on the findings of two studies conducted between 1 April and 30 June 2003 on private sector 
participation (PSP) in central and eastern Europe and central Asia (ECA) and between August and December 2005. The methodology of the study consisted of the following two activities.

(a) A desk study used for investigating the status and trends of PSP in the region. Altogether more then 90 documents were studied and analysed.

(b) Fieldwork was conducted to provide a detailed analysis of the four focus countries (the Czech Republic, Estonia, Hungary and Poland); a contact database was created with over 50 entries. The database identified the key players of the regulating bodies, private operators, professional associations and unions, journalists, researchers and nongovernmental organisations.

\section{PROCUREMENT LEGISLATIVE FRAMEWORKS}

This section focuses on the successes and failures in developing PPP-related legislation in EU member states and the transition countries in central and eastern Europe (namely the western Balkan sub-region, western newly independent states, Caucasus sub-region countries and central Europe). There is a need for radical democratic and economic reforms in central and eastern Europe in order to overcome the legacy of the central planning. Where governance institutions and democratic trends remain weak, so does the ability to operate a business in a legal and ethical environment. The purpose of focusing on central and eastern European countries is to highlight the disparity in legislation between those countries that have achieved or are moving towards EU accession, and those that may not achieve membership in the foreseeable future.

Public procurement laws have been drafted and implemented in recent years in all countries across the region. Legislation is required to introduce the main procurement rules, such as: the responsibility of the procuring entity (the municipality, for example) to implement and manage procurements for goods, works and services; the role of the approving and authorising officers to sign the procurement contracts; and other rules ensuring transparency, efficiency and preventing conflict of interest. The procurement methods usually stipulated are: competitive shopping; competitive tendering; restricted tendering; two-stage competitive tendering; public procurement methods for consultancy services; direct single source method; and emergency procurement. Provisions on conflict of interest and corruption are also generally included.

The EU is unique among international organisations in having a complex and highly developed system of internal law that has a direct effect within the legal systems of its member states. In contrast to nations such as the United States of America, European nations subscribe to the principle that international law adopted by a nation overrides national law, and hence it is the case that EU law overrides the national laws of its member states.

The resolution following the Green Paper and the public discussions

opposes the creation of a separate legal regime for PPPs but considers that there is a need for legislative initiatives in the areas of concessions, respecting the principles of the internal market and threshold values and providing simple rules for tendering procedures, and for clarification with regard to institutionalised public-private partnerships.

However, any act whereby a public entity entrusts the provision of economic activity to a third party must be examined against the rules and principles of the EC Treaty, in particular the freedom of establishment and the freedom to provide services (articles 43 and 49 of the EC Treaty, ${ }^{4}$ respectively). These principles also include transparency, equality of treatment, proportionality and mutual recognition. The Commission adopted on 15 November 2005 the communication on PPPs and Community law on public procurement and concessions. This communication presents policy options with a view to ensuring effective competition for PPPs without unduly limiting the flexibility needed to design innovative and often complex projects. $^{5}$

Table 1 outlines some of the major actions or initiatives that the EU has taken in the area of PPPs and Table 2 illustrates the recommendations for the EU PPP policy formulation.

The western Balkan sub-region includes five independent states-Albania, Bosnia and Herzegovina (BiH), Croatia, the Former Yugoslav Republic of Macedonia (FYR Macedonia), and Serbia and Montenegro (including the province of Kosovo and Mitohija). Publicly available policies promoting or restricting PPPs tend to be absent in the western Balkan countries, and this impedes the effective application of any existing enabling legislation, such as concession laws or public procurement laws. In fact, public procurement laws have been drafted and implemented in recent years in all the western Balkan countries. Such laws have, however, received criticism for such issues as: transparency and non-discrimination policies that are hard to implement; procurement processes that lack objectivity; and in general the presence of too many possibilities to shift to noncompetitive procedures. In general, commercial legislation in the former Yugoslav republics is still based partly on laws inherited from the former Socialist Federal Republic of Yugoslavia, such laws being largely irrelevant in a modern market economy.

Corruption is reputedly a serious problem in public procurement, particularly in the western Balkan region, with frequent allegations that contracts are awarded on the basis of personal and political relationships between business persons and government officials. The judicial system is also perceived to be susceptible to external political and commercial influence to some degree. At the same time, although legislation outlaws bribery and some prosecutions of government officials for corruption have taken place, enforcement of such legislation is uneven.

The (new) Public Procurement Law (PPL) in Kosovo ${ }^{6}$ provides procedures modelled on existing European procedures and introduces measures required by the relevant EU directives. The new law also establishes new and reforms the old institutions to manage the procurement system: the Public Procurement Agency, the Public Procurement Regulatory Body and the Public Procurement Rules Committee. The new PPL of 2004 represents a big step towards aligning the relevant legal framework in Kosovo more closely with EU requirements; however, the overall weak and incomplete implementation of Kosovo's procurement legislation undermines the efficiency of the system. Procuring entities (some 500 in total) have not received adequate support 


\begin{tabular}{|c|c|c|}
\hline Date & Action & Source \\
\hline 1993 & White Paper on growth, competitiveness and employment & $\operatorname{COM}(93) 700$ \\
\hline 1997 & High Level Group on PPP financing of TEN-T projects (Kinnock report) & COM (97) 453 \\
\hline 2000 & $\begin{array}{l}\text { Commission's interpretative communication on concession under } \\
\text { community law }\end{array}$ & $\begin{array}{l}\text { Official Journal of the European } \\
\text { Communities OJEC (2000/c I2I/02) }\end{array}$ \\
\hline 2000 & $\begin{array}{l}\text { Proposal for a regulation of the Council and Parliament concerning the } \\
\text { granting of aid for the coordination of transport by rail, road and inland } \\
\text { waterways }\end{array}$ & $\operatorname{COM}(2000) 5$ \\
\hline 2001 & White Paper on European transport policy for 2010: time to decide & COM (200I) 370 \\
\hline 2002 & Building a valuable approach to PPPs. Working session on the draft guidelines & COM (200I) 370 \\
\hline 2003 & $\begin{array}{l}\text { Guidelines for successful public-private partnerships. DG regional policy and } \\
\text { dissemination at a series of international conferences }\end{array}$ & Director General Regional Policy \\
\hline 2003 & $\begin{array}{l}\text { A European initiative for growth: investing in networks and knowledge for } \\
\text { growth and jobs }\end{array}$ & COM (2003) 690 final \\
\hline 2003 & $\begin{array}{l}\text { Proposal for a decision of the European Parliament and the Council amending } \\
\text { decision No. 1692/96/EC on community guidelines for the development of } \\
\text { the TEN-T }\end{array}$ & $\begin{array}{l}\text { COM (2003) 564; adopted on } 2 \text { I April } \\
2004\end{array}$ \\
\hline 2003 & $\begin{array}{l}\text { Regulation amending Council Regulation (EC) no. } 2236 / 95 \text { laying down } \\
\text { general rules for the granting of Community financial aid in the field of TEN-T }\end{array}$ & $\begin{array}{l}\text { Adopted on } 30 \text { March 2004; awaiting } \\
\text { publication in OJEC COM (2003) 56I }\end{array}$ \\
\hline 2003 & $\begin{array}{l}\text { Developing TEN-T: innovative funding solutions and proposal for a directive } \\
\text { on the widespread introduction and interoperability of electronic toll } \\
\text { collection systems. Communication from the Commission }\end{array}$ & COM (2003) I32 final \\
\hline 2003 & High level group report on the TEN-T networks (Van Miert report) & DG Transport \\
\hline 2004 & Eurostat proposal on accounting treatment of PPPs & $\begin{array}{l}\text { Committee for Monetary, Financial and } \\
\text { Balance of Payments statistics and } \\
\text { Eurostat news release (STAT/04/I8), } \\
\text { February } 2004\end{array}$ \\
\hline 2004 & New procurement directives, including introduction of competitive dialogue & $\begin{array}{l}\text { Adopted in February; awaiting } \\
\text { publication in OJEC }\end{array}$ \\
\hline 2004 & $\begin{array}{l}\text { Green Paper: EU consultative paper on PPPs and community law on public } \\
\text { contracts and concessions }\end{array}$ & COM (2004) 327 final, May 2004 \\
\hline 2005 & $\begin{array}{l}\text { Report on the public consultation on the Green Paper on Public-Private } \\
\text { Partnerships and Community Law on Public Contracts and Concessions }\end{array}$ & SEC(2005) 629 \\
\hline 2006 & $\begin{array}{l}\text { European Parliament resolution on public-private partnerships and } \\
\text { Community law on public procurement and concessions }\end{array}$ & 2006/2043(INI) \\
\hline
\end{tabular}

in the application of the PPL and the skills deficit in this area remains very high.

With regard to public procurement legislation Bosnia and Herzegovina (BiH), in the autumn of 2004 the Council of Ministers agreed on the Law on Public Procurement. The legislation is expected to ensure that fair and transparent procedures are applied to all public purchases. As of 2005, $€ 300-400$ million euros were being spent annually on public procurement at all administrative levels in $\mathrm{BiH}$; the Law on Public Procurement is meant to establish an efficient, effective and modern legal framework to regulate such transactions. The PPL provides for the establishment of two independent organisations dealing with public procurement issues: the Public Procurement Agency (article 48), reporting to the Council of Ministers, and the Procurement Review Body (article 49), reporting to parliament.

The four countries that make up the western newly independent states (NIS)-Belarus, Moldova, the Russian Federation and Ukraine-face many challenges in the course of adapting the PPP framework for public service delivery. The most vivid

(a) To improve understanding of PPPs in the EU institutions, the Commission should set up a cross-EU PPP Group, supported by a small central unit, to coordinate activities affecting PPPs and assess the impacts which EU actions have on their development.

(b) The EU should address the poor level of public sector institutional capacity and knowledge about PPPs in many member states by funding several initiatives, including studies on the actual benefits PPPs can deliver, the provision of training and the secondment of private sector specialists and civil servants to, and between, the PPP units of member states.

(c) The EU should clarify the way that its directives, regulations and legislation interact with PPP procurements although, since PPPs are hard to define and vary greatly across Europe, a legislative approach from the Commission is neither practical nor desirable.

(d) As the EU is open to private finance being used as a form of co-financing, it should assist member states to address the challenging issues involved in combining EU funding with private sector finance and PPPs, helping member states to implement pilot projects, from which practical guidelines can be produced.

Source: PricewaterhouseCoopers plc. ${ }^{3}$ 
challenge is the lack of an investment climate that would attract private companies into the public service delivery sector. The investment climate in Belarus is one of the most challenging in the NIS. The country has a highly centralised system of economic management, state intervention, a privatisation programme that has for the most part come to a halt and a banking system that is controlled primarily by central government. This situation has led to the private sector playing an insignificant role in public service delivery in Belarus, while those enterprises that do exist operate under the close control of central government bodies. A significant trend in the Russian Federation has been the growing role of the domestic private sector in public services provision in recent years. Among other things, this has highlighted the shortcomings of the country's existing legal and institutional arrangements, and has prompted the Russian government to launch a major programme of legislative reform. Local governments, in particular, face major challenges when negotiating contracts with private operators.

In Moldova the obstacles to private sector involvement in the provision of public services include contradictory laws and legislation which is poorly supported and implemented, so undermining the usefulness of-and investor confidence inspecific laws. Despite laws on procurement and concessions that correspond quite closely to international standards, there is a wide gap between the law as written and its implementation in Moldova. Moldova's current Law on Procurement of Goods, Works and Services for Public Needs (No. 1166-XII, 30 April 1997) is based largely on the United Nations Commission on International Trade Law (UNCITRAL) model and provides a reasonably sound basis for public procurement. It was prepared with assistance from an international legal consultant and financed by an Institutional Development Fund (IDF) grant from the World Bank. The law contains a number of weaknesses, which have the effect of reducing transparency in the conduct of public procurement. Foremost among these are the items listed here.

(a) Bid evaluation methodologies that are based on subjective, merit point-based systems, rather than on objective criteria.

(b) Limited provisions on the procurement of consultants' services.

(c) Inadequate arrangements for the review of bid protests. An administrative review of bidders' appeals is undertaken by the National Agency for Government Procurement (NAGP). Given the close involvement of the NAGP in the execution of public procurement, including both its conduct of procurement procedures and approval of award decisions, the ability of the NAGP to act independently in reviewing bidders' appeals is clearly open to question.

Since its adoption the application of the public procurement law has been undermined by the absence of a comprehensive set of implementing regulations.

Although PPPs are possible via lease or concession arrangements, legislation in the Ukraine prohibits the sale of networks and equipment used in the provision of public services to private investors. This means that it is not possible to constitute a joint venture between a municipality and a private firm to provide public services. Frequent changes to legislation act as a further hindrance to business. While modification of the legal framework inherited from the command (socialist) economy is a normal process of transition, numerous changes to regulations preclude entrepreneurs and politicians from developing long-term strategies. Legislative instability also sets the stage for inconsistent and inaccurate interpretation of regulations and legal acts, and this in turn feeds corruption. Many entrepreneurs, for example, believe that Ukrainian agency officials are often unpredictable in interpreting legislation. This then prompts entrepreneurs to resort to unofficial payments to tip decisions in their favour.

Dozens of laws, normative acts, and executive orders addressing decentralisation have been passed in each of the Caucasus sub-region countries over the past decade. Armenia, Azerbaijan and Georgia have designed projects aimed at improving local governance for implementation with the help of international and Western organisations. The countries continue to pursue efforts to conform to European and international legislative standards. Despite such progress in legislative and executive development, there remain three factors that considerably impede the expansion of local government institutions.

(a) The legislative base remains underdeveloped. Several important laws have not yet been adopted, allowing the existing legal framework to remain largely insufficient.

(b) Existing laws are often contradictory. These require revision, as there are manifold inconsistencies among laws, and even among separate clauses of the same law.

(c) There is a lack of legal discipline. Many laws do not work in practice, due to large-scale corruption in governmental structures, flaws in legislation, and extremely low levels of administrative professionalism.

The Law of Georgia 'On the Procedure for Granting Concessions to Foreign Countries and Companies' was adopted in 1994 and amended in 1996 (the 'Concession Law'). The law applies to foreigners only, thus discriminating against domestic investors and excluding these from concession arrangements. The Concession Law defines concession as a 'leasing agreement' for the purpose of foreign investment. The Law seems to limit its scope of application to natural resources and activities related thereto. It contains a vague reference to 'an authorised body as defined under legislation of Georgia', as the public authority to grant concessions. There are numerous deficiencies in the law; for example the selection procedure is not defined in the Concession Law, nor is the disputes settlement procedure. The Concession Law, however, contains a number of positive elements: the concessionaire's right to appeal to the court or arbitration court 'against public organs for their abuse of power' and provision of certain forms of government support/guarantees.

The European Bank for Reconstruction and Development (EBRD) Assessment of Concession Laws undertaken to evaluate the status of laws throughout the EBRD's 27 countries of operations ranked the concession laws in Georgia as in very low compliance with international standards. The law is one of the weakest in the region and is regarded as an early (and outdated) attempt to govern concession arrangements at the start of reforms. Ten years after its enactment, the Concession Law is expected to be fully revised in order to facilitate private sector participation in infrastructure, public utilities and services to match the needs of a modern economy.

The central Europe region is represented by a number of new member states and countries that are going to join the EU in future accession rounds. For instance, Bulgaria and Romania 
joined in 2007. Romania has developed legislation to entrust the private sector with public assets management through rental, concessions and other forms of public-private partnership. A specific PPP law defines 5 types of contracts (build-operatetransfer, design-build-operate, build-operate-renewal, leasingdevelopment-operate, and refurbish-operate-transfer). Bulgaria has weak PPP legislation, yet private sector involvement is more advanced than in other countries in the region. Some of the PPP forms between municipalities and private companies in Bulgaria include: contracting; the establishment of joint venture or shareholding companies; concession on municipal property or the right to use and/or build on such property; the sale of municipal property under certain conditions; concessions on building rights; and use of municipal property in order to carry out maintenance. Turkey started membership talks in the autumn of 2005. In 1994 the Turkish government made amendments to the constitution and embarked upon structural reforms of its key public sector services. None of these countries had a specific PPP unit, although there are discussions about the need for such units. Institutions that deal with privatisations (the privatisation administration in Turkey) and specific ministries (the water and environmental protection ministry in Romania) currently tackle PPP-related questions.

The Croatian Law Center (CLC) was established in 1994 with the support of the Open Society Institute-Croatia. The main goal of the CLC is to promote the rule of law in Croatia through such means as establishing legal principles that are in accordance with international standards, advancing professionalism in the judiciary and supporting general legal research. The CLC is working on revising legislation that will initiate local self-government reforms. The various components of the CLC's activities are

(a) decentralisation of public administration

(b) fighting corruption

(c) access to justice

(d) protection and development of human rights.

A survey of existing procurement law in central and eastern Europe suggests that such laws appear to have several weaknesses.

(a) Across the region, some frameworks adhere in part to international standards and to good practice in public procurement whereas other laws are more rigid, costly, time-consuming and bureaucratic than the EU regime and also less flexible.

(b) In certain cases, inadequate respect for the rule of law does not allow for adequate and fair enforcement of enacted rules. This has resulted in corruption at the local level.

(c) Legal discrepancies, a lack of objectivity and the lack of appropriate systems, procedures and mechanisms have fostered abuses of power.

(d) Overlapping functions and responsibilities of different levels of government, the absence of real decision-making powers, and the lack of financial resources (due to deficiencies in intergovernmental fiscal relations) have further reduced the effectiveness of legal frameworks for PPPs.

\section{MODELS OF PROCUREMENT-INSTITUTIONAL FRAMEWORKS}

Effective legal, regulatory and contractual conditions are crucial for the success of procurement, but such conditions can only perform successfully when they are based on and supported by a country's institutional framework. This institutional structure should aim at both facilitating procurement and providing clear boundaries to protect the interests of all stakeholders. ${ }^{7}$ The institutional framework is crucial if the public sector is to change its role from that of a single provider of services to fulfilling the duties of an independent regulator and manager.

Three approaches to intervention are usually defined, ${ }^{8}$ depending on the degree of centralisation of PPP institutions in a country's overall state structure

(a) highly centralised (e.g. western newly independent states)

(b) highly decentralised (e.g. France and Portugal)

(c) mixed centralised and decentralised (e.g. Ireland, the UK, Italy and the Netherlands).

The western NIS's institutional framework for PPP facilitation is among the most centralised. For example there is no specific PPP-related institution in Belarus or the Republic of Moldova to support the delivery of public services. Different ministries and agencies are responsible for provision of particular services through PPPs, often duplicating each other's functions.

A highly decentralised model has been developed in Portugal and France. Within this model, governments have not established any specific institutions to facilitate or coordinate delivery on numerous initial projects in both the roads and water sectors. PPPs are, however, becoming an important element of municipal planning in France and Portugal, thus the management of projects has very much been left to individual government departments and local authorities. 'Informal task forces' have been established, however, in order to advise on possible PPP forms, legal barriers and institutional structures. ${ }^{8}$ In France, the decentralised approach places the responsibility at the regional level and within the ministries concerned. ${ }^{7}$

Spain is similar to France, with decentralised governance established at the state level; this moves the possible PPP institutional and legislative developments to the city or regional level. ${ }^{9}$ With more and more cases of PPPs and a growing realisation of the need for regulation, some form of central coordination may well develop in the decentralised PPP countries mentioned here, as has been the case in most other countries to date.

The UK, Ireland, Italy and the Netherlands have selected a more centralised approach by creating one dedicated national PPP unit. In the indicated range of centralisation, these examples may be referred to as a mixed (centralised and decentralised) model. In the majority of cases, centralisation is reflected in the creation of a separate PPP unit in the country within a certain ministry with joint public and private participation. At the same time, there is a degree of decentralisation to this approach, because separate units do not implement the projects (implementation is still the responsibility of the relevant department, agency or local authority).

In the Netherlands, a PPP Knowledge Centre has been established within the Ministry of Finance, staffed by representatives of the private sector and the Ministry of Finance and Economic Affairs (Ref. 10, footnote 20). The main 
responsibilities of the unit are the dissemination of PPP

knowledge and best practice, as well as promoting the use of PPPs.

In Italy, a temporary government body has been established within the Economic Policy Committee, with joint representation of the Ministry of Public Works, Finance, Treasury and the private sector. The closely defined functions of the unit include encouraging private sector involvement, addressing deficiencies in the current legislative framework, advising contracting authorities on taking projects forward and the promotion of PPPs.

The Irish PPP institutional framework was developed using, to a great extent, that of the United Kingdom as an example. A central PPP unit, based in the Department of Finance, has been established as part of the Irish model. The unit does not deliver projects and, apart from providing best practice guidance, has a limited role in project support. The aims of the unit are, rather, to manage the PPP programme, national market development, national stakeholder engagement and national policy development in the area of PPPs. ${ }^{10}$ The Interdepartmental Group (IDG) on PPPs is the key public sector forum of the institutional structures established by Government to manage the development of PPPs in Ireland. The main task of the IDG is to ensure consistency in the implementation of Ireland's PPP programme across the public service and to develop issues cutting across all the sectors involved in the PPP programme.

The model developed in the UK has evolved enormously since 1994 up until recently. During the early 1990s, a central body, The Private Finance Panel Executive, was established to develop policy and best practice, but with limited project delivery or support functions. The Labour government replaced that body with the Treasury Taskforce, which was located within the Treasury. Being
Member states

\section{Austria}

Belgium

Denmark

Finland

France

Germany

Greece

Ireland

Italy

Luxembourg

The Netherlands

Norway (not EU)

Portugal

Spain

Sweden

UK

New member states

Cyprus

Czech Republic

Estonia

Hungary

Latvia

Lithuania

Malta

Poland

Slovakia

Slovenia

Bulgaria

Romania

Applicant countries

Turkey

Balkans

Albania

Bosnia and Herzegovina

Croatia

Kosovo

Macedonia

Serbia and Montenegro
Discussions ongoing

$\square \square \square \square$ staffed with civil servants and private sector experts, this body had both policy development and project support roles. In 1999 HM Treasury transformed the Taskforce, with responsibility for policy development being assigned to the new Office for Government Commerce and the project support role to the new Partnerships UK, a joint venture company established by the Treasury and a number of private companies holding a majority stake (Ref. 10, footnote 25).

In all the above listed cases, policymakers within the countries have realised the importance of placing experts within units to

PPP unit $\quad$ PPP law* Relative PPP experience (water and wastewater sector) ${ }^{*}$
$\Delta \mathbf{\Delta} \Delta$

$\Delta$

$\mathbf{A}$

$\Delta$

$\Delta \mathbf{\Delta}$

$\Delta \Delta \Delta$

$\Delta \mathbf{\Delta}$

$\boldsymbol{\Delta} \mathbf{\Delta} \Delta$

$\mathbf{A}$

$\Delta \mathbf{\Delta}$

$\Delta \boldsymbol{\Delta} \Delta$

- $\Delta$

$\Delta$

$\Delta \Delta$

$\Delta \mathbf{\Delta}$

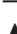

$\Delta \Delta$

$-$

$-$

$\Delta$

$\Delta$

$-$

$-$

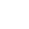

$-$

Information is not available

Need for PPP unit identified and some actions taken (or only a regional unit available)

PPP unit in progress (or existing, but in a purely consultative capacity)

PPP unit existing (and actively involved in PPP promotion)

Legislation being proposed

Comprehensive legislation being drafted/some sector-specific legislation in place

Comprehensive legislation in place

Projects in procurement

Many procured projects, some projects closed

Substantial number of closed projects

Substantial number of closed projects, but a number of them in operation

Source: *Adapted from PricewaterhouseCoopers plc. ${ }^{3}$

Table 3. PPP institutional development 
guide and manage the PPP process. In the beginning, such PPP units focused particularly on developing capability, the required legal and regulatory structures, market interests and pilot projects in order to test the value of PPPs. However, with time the focus has shifted towards assisting the selection of PPP opportunities, counselling and advice, ensuring value for money, attracting investors and above all maintaining political support and the trust of stakeholders (Ref. 10, footnote 21).

Table 3 evaluates the degree of institutional and legislative progress in the area of PPPs in the EU and accession countries. This figure provides a relative assessment of PPP legislative development and actual PPP progress in focus countries. This conclusion is, however, based on a trend, not precise data and thus should be considered as the observation results.

\section{COMPARISON OF NEW EU MEMBER STATES}

From the legislative point of view, all EU member states have to comply with the aquis communitaire-basic directives, the EU Treaty and other legislation regulating the functioning of the EU. PPP procurement procedures, however, have no defined status in the regulatory framework of the EU; as a consequence, each member state, including the new member states, has to develop its own PPP legal and institutional framework. In new member states, this enhancement has been influenced greatly by the EU's financial aid requirements, existing legislative and institutional traditions. The examples of the Czech Republic, Hungary and Poland are provided below for comparison. Poland, Hungary, and Czech Republic are first-tier EU accession countries. These countries have undergone a significant reform of the sector. There are also inflows of capital available from domestic and foreign sources due to the countries' macroeconomic performance, availability of accession funds, efficiency of the utilities concerned and the countries' regulatory and policy environments. The main challenge for these countries is to continue improvements in their institutions and to mobilise the enormous resources needed to meet stringent EU standards. The market is also quite attractive to PPP because of political stability, stable currencies and skilled workforces. ${ }^{11}$ However, support is still being provided by international financial institutions to the water sectors for capital renovation and expansion in the form of grants and soft loans; this is because of the lack of investment commitment to infrastructure from the private operators.

\section{I. The Czech Republic}

New rules for PPP projects involving construction works or infrastructure and other services came into force in March 2006: the Law on Public Contracts and the Law on Concession Contracts and Concession Procedures were adopted. The Public Contracts Law establishes the central purchasing body. The first application of the new rules is the transport projects that are already approved by the Government as PPP pilot projects. The PPP concession contracts involve the following conditions.

(a) The concessionaire agreeing to provide services and/or construction works.

(b) The public authority agreeing to let the concessionaire benefit from those services or works.

(c) The concessionaire bearing a substantial part of any risks involved in that benefit.

(d) The concessionaire being able to receive payments from the public authority.
(a) Public Procurement Act (PPA)
(b) No specific PPP legislation, but amended existed legal base
(c) Law on Public Contracts
(d) Law on Concession Contracts and Concession Procedures
(e) Institutional set-up development is under way

Table 4. Summary of the PPP legal framework in the Czech Republic

With these two laws the Czech government took a more programmed and systematic approach to PPPs. Changes to legislation specifically concern particular tasks such as procurement, concessions, and other fields of legislation. The Czech government has also looked at the institutional set-up (Table 4).

Existing PPP projects in the Czech Republic include waste management, water supply projects, transportation systems (construction and maintenance of roads and railways), information technology, public lighting in Prague and education.

\subsection{Hungary}

PPP projects have gained significant importance over the past few years in Hungary. In fact, some experts claim that Hungary has the most mature PPP market in the region, although it has historically been ambivalent. Given this basis, the Ministry of Economy and Transport plans to review the current legislation to assess whether changes to the existing legislation or the introduction of a completely new law on PPPs would be appropriate to improve the legal framework to facilitate the implementation of PPP projects (Table 5).

The new Act CXXIX of 2003 on Public Procurement (PPA) does not contain any special rules relating to the creation of PPPs. Whether an agreement creating a PPP falls within the scope of the PPA is to be determined on a case-by-case basis. The creation of a PPP is, however, usually based on an agreement awarded through a public procurement procedure, as the subject matter of the agreement is usually a works or service concession and the value of the agreement typically exceeds the public procurement thresholds. The procuring authority for a PPP generally qualifies as a contracting authority for the purposes of the PPA, as the PPA contains a rather broad definition of contracting authority.

\subsection{Poland}

Before 2005 there was no special law for PPP projects in Poland. The small number of common public and private projects were realised under existing laws, which were mainly the Public Procurement Act and the Civil Codex Act. Since

(a) Legal changes ongoing

(b) History of private involvement in roads

(c) 199| Concessions Act

(d) Parliament needs to approve larger projects (that is, projects larger than $€ 95$ million)

(e) New Public Procurement Act regulates PPPs on a case-bycase basis

(f) PPP law is being considered

Table 5. Summary of the PPP legal framework in Hungary 

(a) Draft PPP legislation under development
(b) Public Procurement Law
(c) Various road projects under development
(d) PPP is the big challenge for Poland
(e) No experiences with new PPP law
(f) Good political climate
(g) Trust between the partners
(h) State aid available for PPP projects

Table 6. Summary of the PPP legal framework in Poland

Poland joined the EU, the idea of preparing the legal framework for the cooperation between public and private entities came back with a new dynamic (Table 6).

The parliament adopted the Public Private Partnership Act in July 2005. The act established the platform for realisation of PPP projects. The Public Procurement Act (29 January 2004) preceded the Act and three ordinances on PPP have been issued, to deal with some of the practicalities of PPP projects introduced by legislation last year.

(a) On the scope, rules and procedures for supplying information to the Minister of Economy by the public body entering into a PPP project.

(b) On risk allocation in PPP projects. The specific risks are to be allocated in the most appropriate way, taking into account each party's abilities and experience in risk management.

(c) On the scope of the feasibility studies for PPP projects. This requires public bodies to conduct a wide range of studies to show that using PPP for the project is in the public interest.

\section{CONCLUSIONS AND RECOMMENDATIONS}

This paper has provided a survey of the legislation and institutions developed for infrastructure procurement through PPPs across Europe. Underinvestment and an urgent need for upgraded and expanded infrastructure pressurise the search for alternatives to public sources of funding. Inefficiencies, lack of modern operating and managerial techniques and limited access to technologies encourage partnerships with the private sector companies that have this expertise. In order to further encourage the private sector to increase its involvement, sector reform is required in order to put in place institutional and legal frameworks. Thus, an enabling legal environment, which allows different PPP options and clearly specifies the rules of play, needs to be put in place before launching PPP. In fact, PSP is only possible/useful to the degree that it is supported by the local framework. Furthermore, if government is to change from being a direct service provider to an independent manager, monitor and regulator, the public sector needs to establish a working institutional framework. All functions within this framework need to be carried out with an in-depth understanding of the motives of the private sector; in this way, the balance between these motives and safeguarding public interests can be achieved.

\section{I. Recommendations}

The research found that legislation should be more stable with less frequent changes (e.g. western NIS countries and in particular Ukraine). In most cases legislation still needs to be developed to enable private sector participation in public service delivery. A lack of everyday, institutional support for contracting entities results in low-quality implementation of the existing procurement law. The weak institutional framework across the region requires special attention before PPPs can be considered as a tool utilised on the national scale. Existing PPP examples are mostly based on a case-by-case basis and often are built upon personal connections and relations with the local government authorities.

The research found that current obstacles to effective procurement via legislative and institutional frameworks include the following.

(a) The legal frameworks are often highly complex, challenging and in many situations inconsistent.

(b) The efficiency of the country's procurement legislation is also undermined by weakness in its law enforcement mechanism.

(c) Administration, law enforcement and the judiciary throughout the region are characterised by a lack of impartiality, accountability and transparency.

(d) Central government is still directly involved and plays a crucial role in every large procurement procedure, for example in Kosovo, yet often does not have sufficient resources or capacities to carry out this task.

(e) Unclear demarcation of functions between local and central government.

(f) The lack of a transparent and predictable legal and regulatory framework within which to establish and operate a business impedes investment in the region. The relatively poor (although improving) investment climate appears to be the biggest impediment for PPP development.

Conditions that will ensure success usually include the following conditions.

(a) Strong political support, particularly in creating and managing suitable structures for policy development and procurement.

(b) The establishment of a central public procurement institution may improve the situation provided that the new institution will be staffed and funded adequately and that its professionalism will be safeguarded.

(c) The majority of models (the Irish experience, in particular) emphasise the necessity of stakeholders' cooperation if procurement is to be effective.

(d) The key role of separate (central) PPP units is to create trust, in order to decrease risks and therefore costs, as well as to develop open and sustainable partnerships.

The development of national PPP strategies may, however, differ depending on various factors. These factors include: the institutional capacity; regulatory changes; the state of the sector before the transition from a planned to a market economy; the extent of reforms undertaken so far; the macro-economic performance of the countries concerned; levels of household income; disparities between the member states; and the availability of external assistance. Positive examples of PPP legal and institutional base development in the Czech Republic, Poland and Hungary can serve as an example for the rest of the central and eastern Europe region.

This paper recommends that municipalities need greater technical and legal capacity to negotiate contracts with private companies. It is important to explain to the decision-makers the 
consequences of, and parties' responsibilities to, each type of contractual agreement. If this is not feasible, advisory regulators need to be established to consult with and advise municipalities on partnerships with the private sector. There is a necessity to strengthen the 'public' side of partnerships. There is a need for capacity-building programmes on the part of public authorities, as well as the need for further reforms of local administrations and self-governments. Local authorities should be taught to bid effectively and maintain the monitoring of projects on an ongoing basis, keeping regular checks to ensure that the project develops as agreed in the contract. Including members of the general public in the process of monitoring/supervision may ensure the sustainable success of procurement, ensuring trust among all stakeholders.

\section{REFERENCES}

1. European Commission. The Challenge of Environmental Financing in the Candidate Countries. European Commission Communication (COM (2001) 304 final), 2001. See http://europa.eu.int/eur-lex/en/com/pdf/2001/ com2001_0304en01.pdf (last accessed November 2005).

2. WoRLD BANK. World Development Report: Making Services Work for Poor People. World Bank, Washington DC, USA, 2004.

3. PricenaterhouseCoopers Plc. Developing Public Private Partnerships in New Europe. A report by PricewaterhouseCoopers plc; 2004. See http:// www.pwcglobal.com/Extweb/service.nsf/docid/ 6FDD654BE69A4B3385256BDC00527C30/\$file/ pwc_PPP_report_final.pdf (last accessed November 2005).

4. European Community. European Community Treaty, Articles 43 and 49. See http://www.eel.nl/documents/ectreaty/ ectreaty.html (last accessed August 2005).
5. EUROPEAN UNION. Initiative on public-private partnerships and Community law on public procurement and concessions, 2005. See http://europa.eu.int/comm/ internal_market/publicprocurement/ppp_en.htm (last accessed February 2008).

6. ORganisation FOR ECONOMic CO-OPERATION AND DeVElopment. Administration Reform Capacities in Kosovo. Sigma Publications, OECD, 2004. See http://www.sigmaweb.org/ dataoecd/44/11/34958314.pdf (last accessed February 2008).

7. European Commission. Guidelines for Successful PublicPrivate Partnerships, 2003. See http://europa.eu.int/comm/ regional_policy/sources/docgener/guides/ppp_en.pdf (last accessed November 2005).

8. PPP Working Group, OfFice of the First Minister AND the DEPUTY FIRST MINISTER. Review of PPPs for Northern Ireland, 2002. See http://www.ofmdfmni.gov.uk/ppp/mainreport/ index.htm (last accessed November 2005).

9. ABADIE R. The regulatory and legal environment for PPP. Conference presentation: PricewaterhouseCoopers plc, 2004. See http://lnweb18.worldbank.org/ECA/ecspfExt.nsf/0/ B49DA4889414499BC1256DE800397871?0pendocument EtStart=1\&Count=1000\&ExpandView (last accessed November 2005).

10. LEWIS E. Institutional Support for PPP Programmes: The Irish Experience. Presentation to the Public-Private Partnerships Forum, 2004. See http:// lnweb18.worldbank.org/ECA/ecspfExt.nsf/0/ B49DA4889414499BC1256DE800397871?Opendocument CtStart=1\&Count=1000\&ExpandView (last accessed November 2005).

11. Hill B. Development and financing options for the privatized European water markets. Proceedings of a European Water Market Conference, 3-5 May 2003.

\section{What do you think?}

To comment on this paper, please email up to 500 words to the editor at journals@ice.org.uk

Proceedings journals rely entirely on contributions sent in by civil engineers and related professionals, academics and students. Papers should be 2000-5000 words long, with adequate illustrations and references. Please visit www.thomastelford.com/journals for author guidelines and further details. 